\title{
Evaluation of the subsurface compressed air energy storage (CAES) potential on Gotland, Sweden
}

\author{
Daniel Sopher ${ }^{1}$ (D) Christopher Juhlin ${ }^{1} \cdot$ Tegan Levendal $^{1} \cdot$ Mikael Erlström $^{2,3} \cdot$ Karl Nilsson $^{4}$. \\ José Pedro Da Silva Soares ${ }^{4}$
}

Received: 4 September 2018 / Accepted: 25 February 2019 / Published online: 8 March 2019

(c) The Author(s) 2019

\begin{abstract}
Wind energy is an important field of development for the island of Gotland, Sweden, especially since the island has set targets to generate $100 \%$ of its energy from renewable sources by 2025 . Due to the variability of wind conditions, energy storage will be an important technology to facilitate the continued development of wind energy on Gotland and ensure a stable and secure supply of electricity. In this study, the feasibility of utilizing the Middle Cambrian Faludden sandstone reservoir on Gotland for Compressed Air Energy Storage (CAES) is assessed. Firstly, a characterization of the sandstone beneath Gotland is presented, which includes detailed maps of reservoir thickness and top reservoir structure. Analysis of this information shows that the properties of the Faludden sandstone and associated cap rock appear favorable for the application of CAES. Seven structural closures are identified below the eastern and southern parts of Gotland, which could potentially be utilized for CAES. Scoping estimates of the energy storage capacity and flow rate for these closures within the Faludden sandstone show that industrial scale CAES could be possible on Gotland.
\end{abstract}

Keywords Faludden reservoir $\cdot$ OPAB data set $\cdot$ Gas storage $\cdot$ Baltic Basin $\cdot$ Baltic Sea $\cdot$ Wind power

Daniel Sopher

daniel.sopher@geo.uu.se

Christopher Juhlin

christopher.juhlin@geo.uu.se

Tegan Levendal

tegan.levendal@geo.uu.se

Mikael Erlström

mikael.erlstrom@sgu.se

Karl Nilsson

karl.nilsson@geo.uu.se

José Pedro Da Silva Soares

jose.soares@geo.uu.se

1 Department of Earth Sciences, Uppsala University, Villavägen 16, 75236 Uppsala, Sweden

2 Geological Survey of Sweden (SGU), Kiliansgatan 10, 22350 Lund, Sweden

3 Department of Geology, Lund University, Sölvegatan 12, 22362 Lund, Sweden

4 Department of Earth Sciences, Uppsala Universitet, Campus Gotland, 62167 Visby, Sweden

\section{Introduction}

Wind energy is an area of significant growth within Sweden's renewable sector, where production has increased by approximately 9.1 TWh between 2012 and 2015 (SCB 2018). An important region for wind-energy production in Sweden is the island of Gotland, where a large number of wind turbines have been constructed to take advantage of the favorable wind conditions. In 2013, approximately $40 \%$ (384 GWh) of the island's total electricity consumption was provided by wind power (Byman 2015). The Region of Gotland is working towards its long-term goal of producing $100 \%$ of its energy from renewable sources by 2025 (Region Gotland 2014). Unfortunately, a drawback of wind energy is its fluctuating electricity supply, which arises from daily as well as seasonal variations in wind conditions. On Gotland, these fluctuations can currently be compensated by the power cable connection from mainland. However, as wind production on Gotland develops further, it will likely become more challenging to balance the supply of wind energy via mainland sources to provide stable and secure electricity for the island. 
One solution to the problem of fluctuating wind-energy production is energy storage. Energy storage is a technology which can be used to buffer these variations in wind-energy supply (OECD/IEA et al. 2016). Hence, it has the potential to increase the competitiveness and reliability of wind energy on Gotland, and facilitate its future development. A range of energy storage technologies exist, but some are more suitable for buffering large-scale variations in wind energy than others (Luo et al. 2015). This is due to differing performance characteristics (for example capacity, cycle efficiency, response time, etc.), as well as their applicability given the geological and geographical constraints on Gotland. Presently, Power to Gas is one of the methods which is currently being investigated on Gotland (Byman 2015). With this storage method, excess electricity is used to synthesize hydrogen or methane gas, which, at a later stage, can be utilized as fuel to generate electricity, power vehicles, or as a raw material to synthesize other compounds. A downside of Power to Gas as an energy storage technology is that, if the synthesized fuel is used to generate electricity, the cycle efficiency is relatively low (between 20 and $66 \%$ for hydrogen fuel cells) (Barton and Infield 2004; Schaber et al. 2004; Chen et al. 2009). Furthermore, if the synthesized fuel is being used for chemical production or fuel for transportation, it may not be available to generate electricity when required.

An energy storage method which is capable of storing relatively large amounts of energy at a relatively low cost (Luo et al. 2015) and would be suitable to buffer large-scale variations in wind production is Compressed Air Energy Storage (CAES). To date, opportunities for CAES on Gotland have not been extensively investigated. In CAES, excess energy is used to compress air which is then stored. At a later stage, the compressed air can be extracted and used to produce electricity (Fig. 1). The amount of energy which can be stored is dependent on the properties (for example, storage pressure) and volume of the storage container. Although it is possible to perform CAES using manmade containers, subsurface geological formations are required to provide storage capacities which are meaningful for industrial-scale storage applications. Three main categories for the storage of compressed air within geological formations have been proposed: (1) caverns within salt formations, (2) caverns within hardrock formations, and (3) porous reservoir formations (Giramonti et al. 1978; Succar and Williams 2008). However, of these three alternatives, the best understood is storage within salt formations, which is the type of formation utilized by the two CAES plants currently in operation (Luo et al. 2015).

In a geological context, the bedrock beneath Gotland consists of a sequence of Palaeozoic sedimentary rocks (Cambrian to Silurian in age), which unconformably overlay a heavily eroded crystalline basement sequence (Fig. 1). The thickness of the Palaeozoic rocks beneath Gotland ranges from approximately $800 \mathrm{~m}$ in the southern part of the island to about $300 \mathrm{~m}$ in the north. In terms of potential storage formations, there is an absence of viable salt formations within the Palaeozoic sequence; hence, the most well-understood type of geological formation for CAES is not feasible on Gotland. Furthermore, the second type of storage formation is also not feasible on Gotland, due to the lack of suitable caverns or subsurface mines within the Palaeozoic limestone or in the crystalline basement. However, a number of porous reservoir formations are present beneath Gotland, some of which could be suitable candidates for subsurface CAES. In recent years, these porous formations have been the target of numerous investigations to assess their suitability for storage of $\mathrm{CO}_{2}$ (e.g., Erlström et al. 2011; Vernon et al. 2013; Sopher et al. 2014; SLR and Uppsala University 2014; Lothe et al. 2015; Yang et al. 2015). Based on this work, the highest quality reservoir identified is the regionally extensive Middle Cambrian Faludden sandstone of the Borgholm Formation (Hagenfeldt and Bjerkéus 1991; Hagenfeldt 1994), equivalent to sandstone units in the Deimena Group in Estonia, Latvia, and Lithuania (Jankauskas 1994) (Fig. 1). To date, there are only regional studies dealing with the characterization of this reservoir beneath the island of Gotland. Although the petrology and reservoir quality of the Deimena sandstone units are comprehensively described by, e.g., Kilda and Friis (2002) and Molenaar et al. (2007), these results can only partly be used as references for assessing the Faludden sandstone reservoir properties, since they represent greater burial depths.

In this study, the potential to utilize the Middle Cambrian Faludden reservoir for CAES on Gotland (onshore) is assessed. Initially, a detailed characterization of the geometry of the Faludden reservoir and its properties beneath Gotland is presented. To achieve this, an extensive and largely unpublished database, containing over $2300 \mathrm{~km}$ of seismic reflection profiles and over 300 wells from the island of Gotland, was utilized and interpreted. This allows, for the first time, detailed reservoir structure and thickness maps to be generated beneath Gotland. Furthermore, key reservoir parameters such as pressure, permeability, porosity, and temperature are also assessed. This new reservoir characterization is then utilized to perform a high level assessment of the CAES potential within the Faludden reservoir. As part of the assessment, key requirements for CAES are considered and simple estimates of energy storage capacity and reservoir flow rate are made. The study, therefore, contributes to the understanding of how utilization of the subsurface can help to support the development of additional renewable energy on Gotland. 


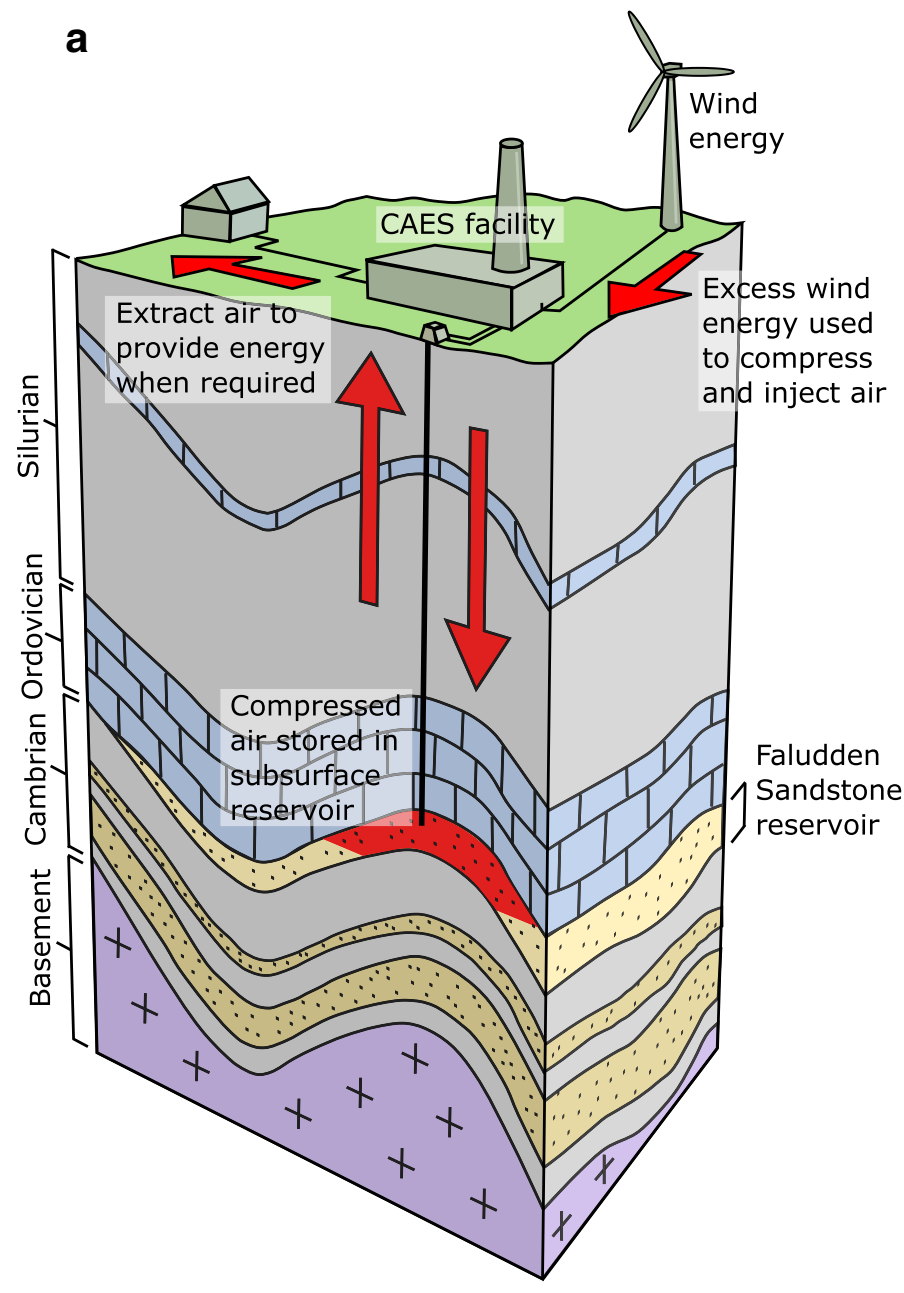

b

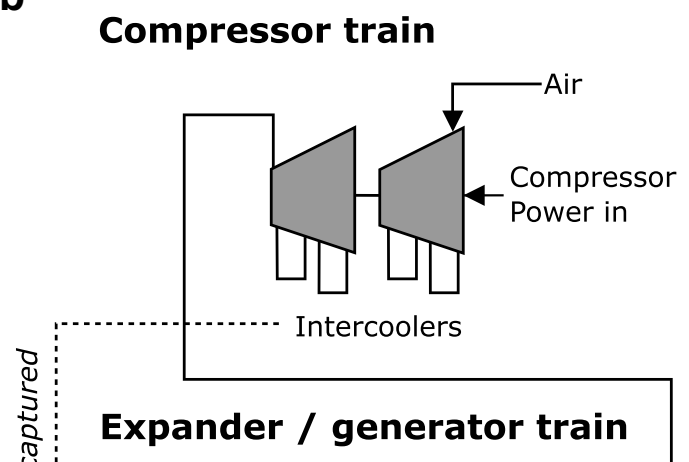

Fig. 1 a Schematic cross section demonstrating the concept of CAES within the porous Faludden sandstone reservoir beneath Gotland. b A schematic of a CAES plant. The solid lines outline the main processes utilized in conventional CAES. The dotted lines indicate addi-

\section{Energy production and storage requirement on Gotland}

In 2015, electricity consumption accounted for approximately $21 \%$ of the total energy (4.6 TWh) used on Gotland (Green and Sorby 2018). Data were obtained from Gotland Energi AB (GEAB), to gain a better understanding of the variations in electricity consumption and production on Gotland. These data consist of average hourly values for consumption, regulation and renewable production (wind/solar), for a 3-year period. The main electricity production source on Gotland is wind power with approximately $180 \mathrm{MW}$ of installed capacity. Solar power also contributes with $3 \mathrm{MW}$ of installed capacity. Both production and demand are regulated by two cables $(2 \times 160 \mathrm{MW})$ connected to mainland Sweden which import or export electricity as required. The island consumes approximately $1 \mathrm{TWh} /$ year of electricity, tional processes utilized in AA-CAES, where heat from the compression stage is stored and used later in the expansion stage, mitigating the need to utilize fuel for heating (figure modified from Succar and Williams 2008)

out of which $54 \%$ is imported and $46 \%$ comes from domestic production. Figure 2 presents cumulative values of the energy production, consumption and regulation (duration diagram) during 2016. Here, the regulation curve can be used to infer the energy export and import from the negative and positive parts of the curve, respectively. Hence, in 2016, about $16.7 \mathrm{GWh}$ was exported and about $564 \mathrm{GWh}$ was imported, where the total time periods of export and import were about 1000 and $7800 \mathrm{~h}$, respectively. Furthermore, during 2016, the longest continuous period of export was $50 \mathrm{~h}$, corresponding to about $1.6 \mathrm{GWh}$ (peak power of $55 \mathrm{MW}$ ). Conversely, the longest continuous period of import was $893 \mathrm{~h}$, corresponding to $71 \mathrm{GWh}$ (peak power of $130 \mathrm{MW}$ ).

To approximate a future scenario, where Gotland utilizes $100 \%$ renewable electricity, a model was developed by Nilsson et al. (2017) (Fig. 2). Here, both solar and wind production on 
a

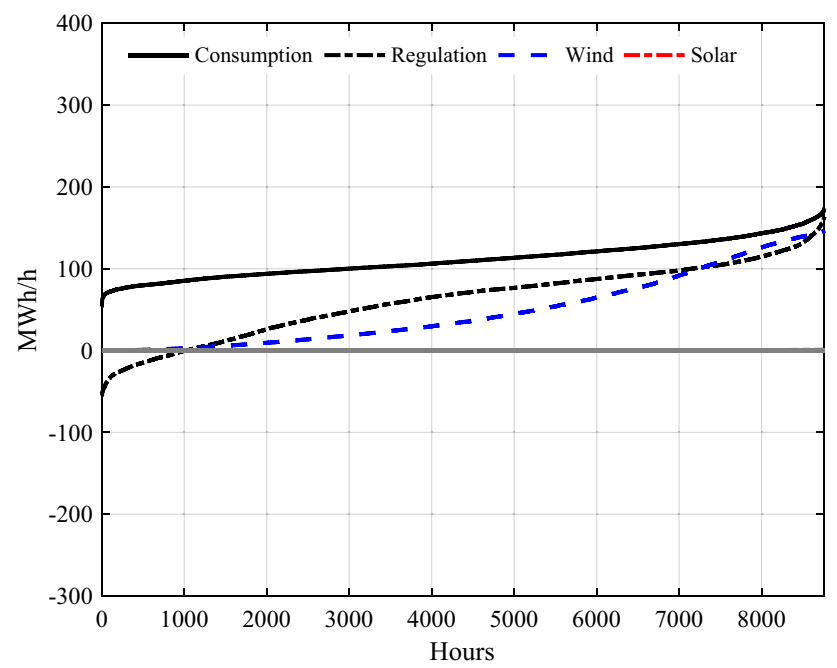

b

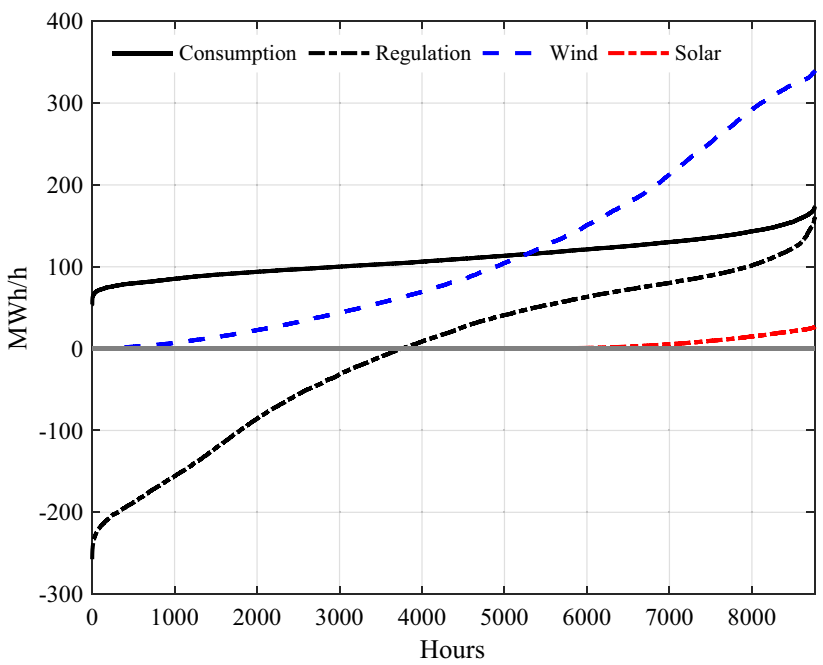

Fig. 2 a Duration diagram of the current (2016) electricity production, consumption and regulation. b Duration diagram showing electricity production, consumption and regulation for a scenario with a 100\% renewable energy system (Nilsson et al. 2017)

Gotland were increased to match the consumption in 2016 on a monthly basis and also for the entire year. This model estimates that, for Gotland to achieve a self-sufficient renewable electrical system (1 TWh annual production), an installed capacity of about $345 \mathrm{MW}$ and $25 \mathrm{MW}$ for wind and solar power is required, respectively. In this modeled scenario, the total annual energy export and import are $380 \mathrm{GWh}$ and $340 \mathrm{GWh}$, respectively. Within this 1-year model, due to the variations in renewable production, the longest continuous period of energy export is $158 \mathrm{~h}$, corresponding to $26 \mathrm{GWh}$ (peak power of $231 \mathrm{MW}$ ). Conversely, the longest continuous period of energy import is $262 \mathrm{~h}$, corresponding to $19 \mathrm{GWh}$ (peak power of $108 \mathrm{MW}$ ). Due to practical considerations, only one cable $(160 \mathrm{MW})$ at a time can be utilized for export, and hence, this scenario exceeds the current cable export capacity. Therefore, it is likely that energy storage will be required on Gotland to accommodate the variations in energy production arising from a $100 \%$ renewable, self-sufficient energy system. In the modeled scenario, a storage system with a maximum capacity of $231 \mathrm{MW}$ ( $26 \mathrm{GWh}$ ) would be needed to fully account for the variations. Hence, this can serve as an estimate of the maximum energy storage requirement on Gotland. However, it should be noted that more detailed investigations need to be conducted, to understand the short-term storage requirements and to better characterize the variability of wind and solar production.

\section{Subsurface CAES background}

In conventional compressed air energy storage (CAES), excess electricity is used to drive a chain of compressors, which draw in and compress air (Fig. 1) (Giramonti et al. 1978; Allen et al. 1983). A large amount of heat is generated as part of the compression process, and hence, a series of intercoolers are utilized to improve the efficiency (Succar and Williams 2008). The air is then stored at high pressure within a storage medium (i.e., a geological formation). When required, the pressurized air is extracted from the storage medium and expanded to generate electricity. To improve the efficiency, fuel (e.g. natural or bio-gas) is combusted together with the compressed air in the expansion process (Fig. 1).

Presently, two plants exist which operate a conventional CAES process. The oldest of the two, the Huntorf CAES plant in Germany, was completed in 1978 and can presently operate for $3 \mathrm{~h}$ with a rated power output of $321 \mathrm{MW}$ (Fig. 1) (Crotogino et al. 2001; Van der Linden 2006). The second, the McIntosh plant in the USA, was completed in 1991 and can operate for $26 \mathrm{~h}$ with a rated power output of 110 MW (Succar and Williams 2008; Raju and Khaitan 2012). Both of these plants utilize artificially mined salt caverns to store the compressed air, with total volumes of 
$310,000 \mathrm{~m}^{3}$ and $560,000 \mathrm{~m}^{3}$ for the Huntorf and McIntosh plants, respectively. Cycle efficiencies for the Huntorf and McIntosh plants are quoted at approximately $42 \%$ and 54\%, respectively (Luo et al. 2014, 2015).

Advanced Adiabatic CAES (AA-CAES) is a new form of CAES which has been proposed where the heat generated in the compression process is captured and stored (Fig. 1) (Power 2010). This heat can be used in the expansion stage and, hence, mitigates the requirement to burn fuel. Although no AA-CAES systems currently exist, a demonstration plant is being developed in Germany as part of the ADELE project (Succar and Williams 2008; Power 2010; Luo et al. 2015; Aghahosseini and Breyer 2018). This site is planned to have a rated output of $90 \mathrm{MW}$, a cycle efficiency of approximately $70 \%$ and to operate with zero $\mathrm{CO}_{2}$ emissions (as it utilizes renewable electricity).

With regards to CAES within porous reservoirs, a number of small pilot scale projects have been conducted. Smallscale testing carried out by the Electric Power Research Institute (EPRI) in Illinois, USA, gave positive indications for the feasibility of CAES within porous formations (Allen and Doherty 1984; Succar and Williams 2008). A 25 MW test facility was constructed in Italy and operated successfully. However, the test was stopped early due to a geological disturbance at the site (Luo et al. 2015). A project to construct a $270 \mathrm{MW}$ porous reservoir CAES facility began in Iowa, USA, in 2003. However, this project was stopped in 2011 after drilling results showed that the reservoir was more heterogeneous and had a lower permeability than expected (Heath et al. 2013). In recent years, there have been a number of reservoir simulation studies to investigate the feasibility of CAES within porous reservoirs (Oldenburg and
Pan 2013; Jarvis 2015; Wang and Bauer 2017). Results from these modeling studies show that, in principle, industrialscale CAES within porous reservoirs is feasible.

\section{Methodology for assessment of CAES potential in porous formations}

Despite the lack of industrial experience, there are a number of studies which outline geological criteria which would be desirable to have in a porous reservoir to be utilized for CAES (Giramonti et al. 1978; Allen et al. 1983; Succar and Williams 2008). One reason this is possible is because a porous reservoir CAES operation bears many similarities to natural gas storage, which is a mature technology that has been in operation for more than 100 years (Zhang et al. 2017). Hence, key requirements of a potential CAES storage site can be inferred from the extensive experience of the natural gas storage industry. Table 1 outlines a list of criteria modified from Succar and Williams (2008), which can be used to rank the suitability of potential sites for porous reservoir CAES. This table lists key geological properties and associated threshold values which are desirable for porous reservoir CAES and will form the basis of the following discussion.

A primary requirement for CAES is the presence of a high-quality reservoir (Giramonti et al. 1978). Specifically, the reservoir should have relatively high porosity $(>10 \%)$, so that there is significant space available for the storage of compressed air. The reservoir should also have a relatively high permeability (>300 mD) to achieve high enough flow rates in and out of the reservoir for CAES operations (Allen et al. 1983). A laterally homogeneous reservoir is also

Table 1 Key reservoir and cap rock properties required for CAES operations, modified from Succar and Williams (2008)

\begin{tabular}{|c|c|c|c|c|c|}
\hline Score & 1 & 2 & 3 & 4 & 5 \\
\hline Score interpretation & Unusable & Marginal & OK & Good & Excellent \\
\hline Permeability (mD) & $<100$ & $100-200$ & $200-300$ & $300-500$ & $>500$ \\
\hline Porosity (\%) & $<7$ & $7-10$ & $10-13$ & $13-16$ & $>16$ \\
\hline $\begin{array}{l}\text { Total reservoir volume } \\
\left(V_{\mathrm{R}} / V_{\mathrm{S}}\right)\end{array}$ & $<0.5$ & & $0.5-0.8$ or $>3.0$ & $0.8-1.0$ or $1.2-3.0$ & $1.0-1.2$ \\
\hline Total closure rating $(h / H)$ & $<0.5$ & & $0.5-0.75$ & $0.75-0.95$ & $0.95-1.0$ \\
\hline Depth to top of reservoir $(\mathrm{m})$ & $<137$ or $>760$ & $140-170$ & $170-260$ or $670-760$ & $260-430$ or $550-670$ & $430-550$ \\
\hline Reservoir pressure $(\mathrm{MPa})$ & $<1.3$ or $>6.9$ & $1.3-1.5$ & $1.5-2.3$ or $6.1-6.9$ & $2.3-3.9$ or $5.0-6.1$ & $3.9-5.0$ \\
\hline Type of reservoir & Highly Discontinuous & $\begin{array}{l}\text { Moderately vugular } \\
\text { limestone \& } \\
\text { dolomite }\end{array}$ & $\begin{array}{l}\text { Reefs, highly vugular lime- } \\
\text { stone \& dolomite }\end{array}$ & Channel sandstones & Blanket sands \\
\hline Residual hydrocarbons (\%) & $>5 \%$ & & $1-5 \%$ & & $<1 \%$ \\
\hline Cap rock leakage & Leakage evident & No data available & Pumping tests show no leakag & & \\
\hline Cap rock permeability $(\mathrm{mD})$ & & & $>10^{-5}$ & $<10^{-5}$ & \\
\hline $\begin{array}{l}\text { Cap rock threshold pressure } \\
(\mathrm{MPa})\end{array}$ & & & $2.1-5.5$ & $>5.5$ & \\
\hline Cap rock thickness (m) & & & $<6$ & & $>6$ \\
\hline
\end{tabular}


desirable to allow predictable and efficient behaviour of the air bubble within the reservoir. Another important requirement for CAES is the presence of a dome or structural closure at the storage site (Fig. 1) (Giramonti et al. 1978). This structural closure serves to trap the bubble of air (due to buoyancy), which will be injected during CAES operations. The closure rating is a factor which describes the proportion of reservoir which is above the lowest closing contour of the closure and is defined as $h / H$ (Succar and Williams 2008). Where $h$ is the thickness of reservoir above the lowest closing contour and $H$ is the total thickness of the reservoir at a given point. A high closure rating is desirable in CAES as this means that the entire reservoir thickness can be filled with air and, hence, the gas water contact will only be present on the flanks of the structure (as shown in the schematic closure in Fig. 1). The depth to the top of the reservoir and its pressure are important in CAES as they define the conditions under which the compressed air will be stored in the reservoir and the required design of the turbo machinery on the surface. Based on existing designs, pressures between 3.9 and $5 \mathrm{MPa}$ are most desirable (Succar and Williams 2008). It is considered undesirable if the amount of residual hydrocarbons within the reservoir is too high $(>1 \%)$, as it can lead to the formation of compounds within the reservoir which can damage its performance or which may lead to increased wear on the machinery within the CAES plant (Succar and Williams 2008). The final key component of a suitable CAES site is the presence of a suitable cap rock or impermeable layer which overlies the reservoir (Giramonti et al. 1978). This layer is important to keep the compressed air within the reservoir layer and prevent it from leaking. Therefore, a suitable cap rock should be present across the entire reservoir area. It should be thick $(>6 \mathrm{~m})$, have a high threshold pressure $(>5.5 \mathrm{MPa})$, have a low permeability $\left(<10^{-5} \mathrm{mD}\right)$ and be shown not to leak during pump tests (Allen et al. 1983; Succar and Williams 2008).

In this study, a simple and somewhat empirical approach is adopted to assess the potential CAES energy storage capacity within a given structural closure. The following equation is utilized:

$E=G \theta N V$,

where $E$ is the total energy storage capacity (MWh), $G$ is the gross rock volume within the closure, $\theta$ is the porosity (unitless, where $0=$ no pore space and $1=100 \%$ pore space), $N$ is the net-to-gross value for the reservoir (i.e., the proportion of the gross rock volume which can be considered to be reservoir), and $V\left(\mathrm{kWh} / \mathrm{m}^{3}\right)$ is the energy stored per unit volume of pore space. If maps of reservoir thickness and top structure are available, then the gross rock volume $(G)$ can be calculated directly from the maps for a given structural closure (Sopher et al. 2014). Values for the porosity $(\theta)$ and net-to-gross $(N)$ can be derived from well log data and core measurements.

The energy stored per unit volume $(V)$ is a complex value to estimate. $V$ not only varies due to geological factors such as the closure geometry, depth and subsurface reservoir conditions, but also due to the design of the CAES facility; for example, the operating pressure range and number of injection/extraction wells, etc. Values for $V$ for the Mcintosh and Huntorf CAES plants, which utilize caverns in salt formations, are approximately 5 and $3.75 \mathrm{kWh} / \mathrm{m}^{3}$, respectively (Succar and Williams 2008). However, these are higher than values for $V$ which one would expect for porous reservoir formations. A key reason for this is that, in CAES operations, the total amount of gas within the structural closure will consist of both working gas and base gas (Allen et al. 1983). The working gas is continuously injected and extracted as part of the CAES operation and hence, is where the energy is stored. The base gas provides pressure support for the working gas and ensures that water below the air bubble does not reach the wells. In natural gas storage operations, the base gas can constitute up to $15-75 \%$ of the total gas in the structural closure. In CAES, even larger proportions of base gas have been suggested. For example, the EPRI recommends that the ratio of base gas to working gas in a CAES operation within a porous reservoir should be approximately 10 to 1 (EPRI 2012). Values of $V$ obtained for porous reservoirs from other studies include $0.105 \mathrm{kWh} /$ $\mathrm{m}^{3}$ (Allen et al. 1983), $1 \mathrm{kWh} / \mathrm{m}^{3}$ based on values quoted for the proposed Iowa CAES plant (Succar and Williams 2008), $0.21 \mathrm{kWh} / \mathrm{m}^{3}$ (EPRI 2012) and $0.61 \mathrm{kWh} / \mathrm{m}^{3}$ (Wang and Bauer 2017). In this study, two values of $V$ are chosen to provide a low case storage capacity estimate $\left(V=0.1 \mathrm{kWh} / \mathrm{m}^{3}\right)$ and a high case storage capacity estimate $\left(V=1 \mathrm{kWh} / \mathrm{m}^{3}\right)$. However, it is important to note that, to obtain an accurate value for $V$ for a given structural closure, reservoir modeling will need to be performed. Therefore, the approach here is only capable of providing a scoping estimate of the storage capacity of a given structural closure.

Another important factor which will be estimated in this study is the flow rate for a given storage reservoir. The flow rate is important as CAES will only operate effectively if the air can be injected and extracted from the storage formation at a reasonable rate (Allen et al. 1983). To estimate the flow rate, the radial flow equation is used (Katz et al. 1959):

$Q_{\mathrm{sc}}=\frac{8.834 \cdot 10^{-3} k h\left(p_{\mathrm{f}}^{2}-p_{\mathrm{s}}^{2}\right)}{\mu T Z \ln \left(\frac{r_{\mathrm{f}}}{r_{\mathrm{w}}}\right)}$,

where $r_{\mathrm{w}}$ is the wellbore radius $(\mathrm{m}), r_{\mathrm{f}}$ is the drainage radius of the well $(\mathrm{m}), p_{s}$ is the pressure at the wellbore (MPa), $p_{\mathrm{f}}$ is the pressure at the formation edge (MPa), $h$ is the formation height $(\mathrm{m}), k$ is the permeability $(\mathrm{mD}), T$ is the temperature in the reservoir $(\mathrm{K}), \mu$ is the viscosity $(\mathrm{cP}), Z$ is the gas 
deviation factor and $Q_{\mathrm{sc}}$ is the flow rate of the well $\left(\mathrm{m}^{3} / \mathrm{s}\right)$. Although this equation is often used to estimate the flow rate from porous reservoirs, it will only give an approximate estimate of the flow rate. In reality, when extracting gas from the reservoir, the pressure in the reservoir will drop over time, and hence, so will the flow rate. This equation does not take this into account, and hence, it is more representative of the flow rate at the very beginning of a period of air extraction from the reservoir. Therefore, this equation only provides an approximate value for the flow rate from the prospective CAES reservoir. Reservoir modeling is required to more accurately estimate the flow rate during CAES cycling operations.

\section{Background geology}

Gotland is located on the NW flank of a broad synclinal basin (the Baltic Basin), which developed primarily during the Caledonian Orogeny as a flexural foreland basin (Poprawa et al. 1999) (Fig. 3). The crystalline basement, which underlies the Palaeozoic strata beneath Gotland and much of the Baltic Sea area, formed during the Svecofennian orogeny (1.95-1.75 Ga) (Nironen 1997). Deposition first began in the Baltic Basin during the Late Pre-Cambrian/Early Cambrian due to subsidence associated with the opening of the Tornquist Sea (Poprawa et al. 1999). Beneath Gotland, the Lower Cambrian (Viklau, När shale, När sandstone and Grötlingbo members of the File Haidar Formation) and Middle Cambrian (Mossberga and Faludden members of the Borgholm Formation) consist of an alternating sequence of sandstones, claystones and siltstones, deposited in a shallow marine environment (Ūsaitytė 2000; Nielsen and Schovsbo 2011) (Fig. 4). In some parts of Gotland, a thin (0-4 m thick) condensed succession of Late Cambrian/Early Ordovician dark organic rich shale (Alum shale) is present above the Middle Cambrian Faludden member. Overlying this is an 80-110 m thick Ordovician succession, consisting predominantly of various carbonate rock types. Increased subsidence rates linked to the Caledonian orogeny (Poprawa et al. 1999) during the Silurian led to the formation of a thick succession (approximately 100-400 m beneath Gotland) of limestones and marls upon the Ordovician strata. Silurian strata form the uppermost bedrock on the island of Gotland, where approximately ten barrier reef complexes are thought to have developed between the Ludlow and the Wenlock (Calner et al. 2004; Eriksson and Calner 2005).

There are a number of potential reservoirs in the Palaeozoic sequence. Of these, the Middle Cambrian Faludden sandstone reservoir is considered to be the highest quality reservoir (Erlström et al. 2011; Vernon et al. 2013; Sopher et al. 2014) and, hence, will be the focus of this study. The Faludden reservoir (Fig. 4) consists of well-sorted, medium-grained quartz sandstone deposited in a shallow marine setting. Within the Baltic Basin, it can exceed $50 \mathrm{~m}$ in thickness and typically exhibits good reservoir properties, with porosity and permeability values ranging from 10 to $18 \%$ and $200-1000 \mathrm{mD}$, respectively (Sopher et al. 2014). The Faludden reservoir is thickest to the south-east of Gotland and gradually decreases in thickness towards the northwest. Beneath the island of Gotland, the reservoir pinches out (reaches zero thickness), and hence, the Faludden reservoir does not outcrop at the surface (Fig. 4). Above the Faludden reservoir, there is a sequence of relatively impermeable rocks (less than $1 \mathrm{mD}$ ), which could be suitable as a cap rock. Specifically, the lowermost Ordovician Bentonitic limestone unit and the lowermost part of the Silurian interval (Sopher et al. 2014; SLR and Uppsala University 2014) are candidate cap rocks. The Bentonitic limestone unit typically consists of micro-crystalline limestone with interbeds of bentonite clay and is between 45 and $60 \mathrm{~m}$ thick beneath Gotland. In some wells to the south of Gotland, accumulations of natural gas have been encountered within structural closures within the Faludden reservoir, demonstrating the viability of the reservoir-cap rock system.

The Cambrian Viklau and När sandstone reservoirs (Fig. 4) represent lower quality reservoirs with comparatively poorer reservoir properties than the Faludden reservoir (i.e., typically lower porosity and permeability) (Erlström et al. 2011; Sopher at al. 2014). The shallowest reservoir, the Silurian Burgsvik sandstone, is poorer in quality than the Faludden reservoir, outcrops on land, and reaches a maximum depth of approximately $150 \mathrm{~m}$ on the very southern part of Gotland. This is typically considered too shallow for CAES applications in porous reservoirs (Succar and Williams 2008). Therefore, these reservoirs will not be considered further in this assessment.

\section{Characterization of the Faludden reservoir beneath Gotland}

The data for the characterization work come from an extensive database containing data collected between 1970 and 1990 by the Swedish oil prospecting company (OPAB) (Sopher and Juhlin 2013; Sopher 2017). The OPAB data set contains well reports and geophysical well logs from over 300 wells located primarily on Gotland, but also offshore. Furthermore, the data set contains over $2300 \mathrm{~km}$ of 2D seismic reflection data from the island of Gotland. To date, the vast majority of these data have not been published and were recently made available for academic use by the Geological Survey of Sweden (SGU). Initially, the majority of the seismic reflection data from Gotland were only available as scanned images (TIFF files) of the final stacked data, which made the data difficult to fully 
a
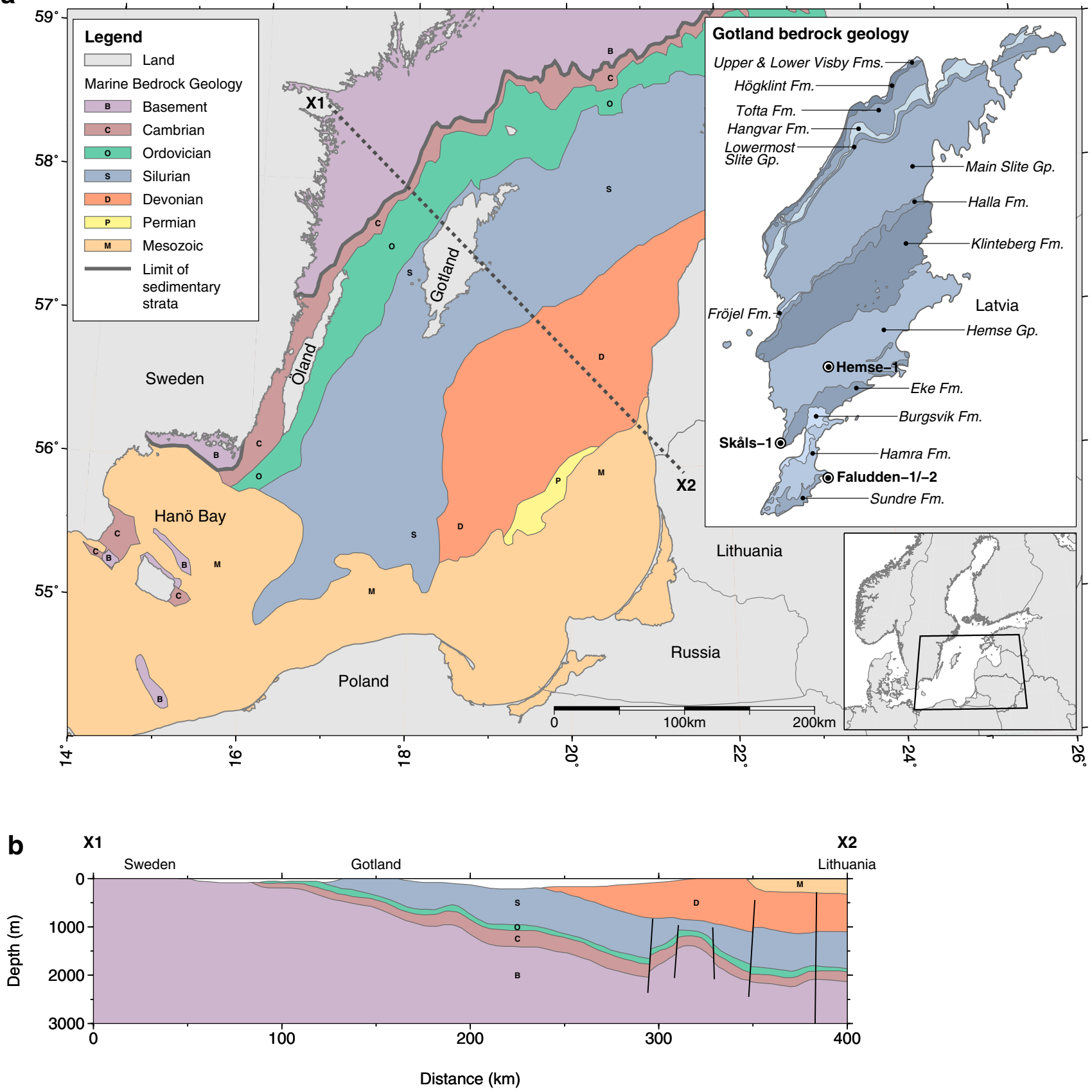

Fig. 3 a Marine bedrock map modified from Sopher et al. (2014). The small inset map in the bottom right-hand corner of the image shows the location of the main map within northern Europe. The larger inset map in the top right-hand corner of the image shows the detailed bedrock of Gotland after Eriksson and Calner (2005). The projection used for the map is WGS84. b Schematic regional cross section through the Baltic Basin. The location of the schematic cross section is shown in part $\mathbf{a}$ as a dotted line utilize and interpret. Therefore, it was necessary to convert these data to SEGY format (vectorize) before they could be imported into modern seismic interpretation software (Sopher 2017). Similarly, much of the geophysical well log data was digitized by hand, so that the data could be plotted and used to calculate synthetic seismograms.

\section{Faludden reservoir thickness}

Due to the variable thickness of the Faludden reservoir (Fig. 4), a key step in the assessment was to generate an accurate map of the reservoir thickness beneath Gotland (Fig. 5). To generate this map, data from over 130 wells 
a

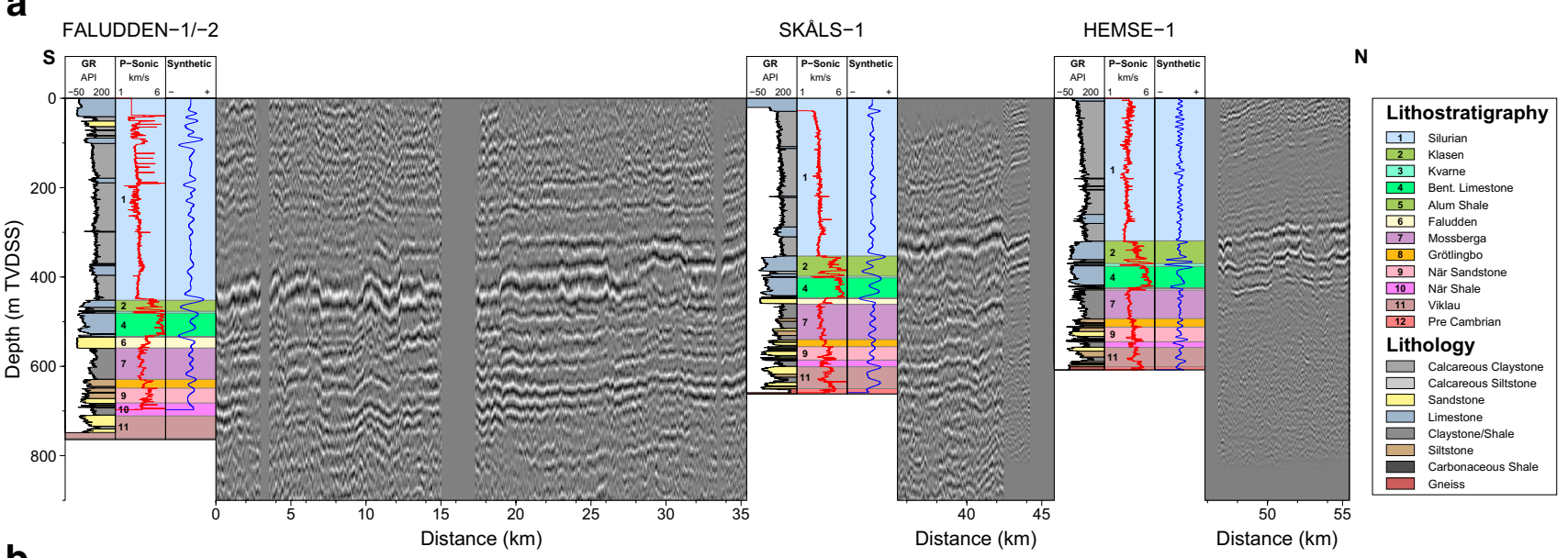

b

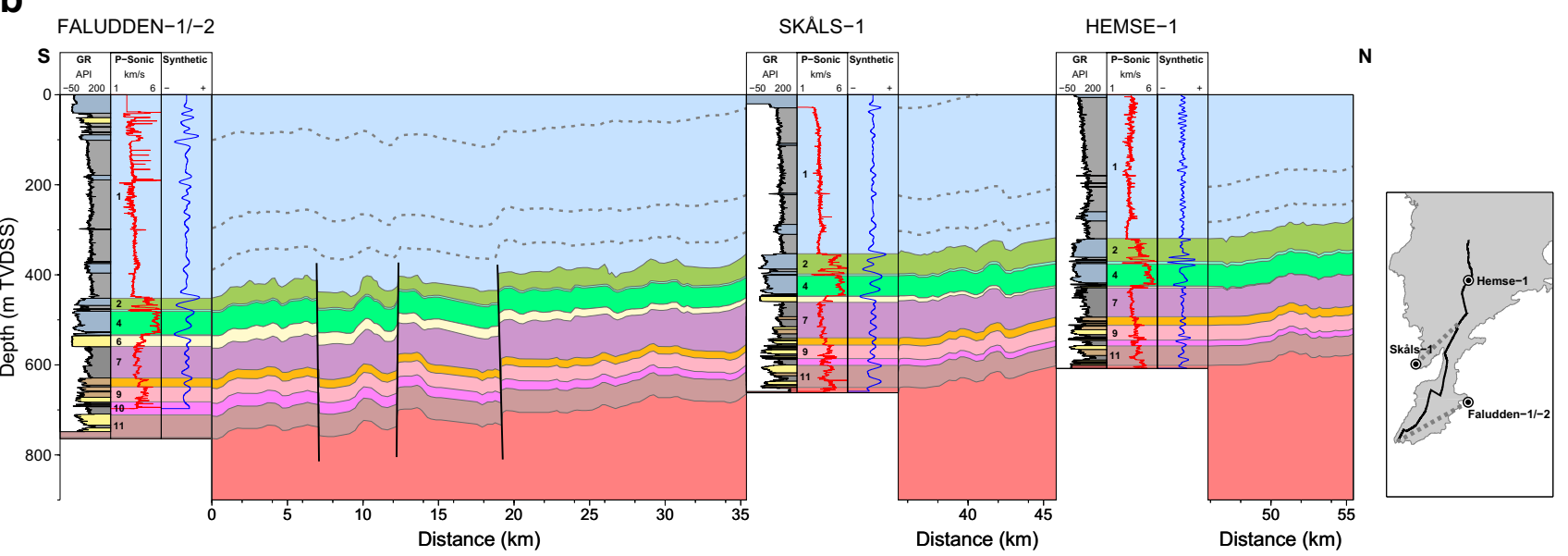

Fig. 4 Seismic and well data correlation panel for an approximate north-south profile across southern Gotland. Natural gamma, P-wave sonic, and a synthetic seismogram are shown for three key wells; note that the wells are projected onto the profile parallel to the general strike of the Palaeozoic succession on Gotland. The Faludden-1/-2 well combines geophysical well log data from both the Faludden-1 and Faludden-2 wells, which are drilled close together. a Depth converted seismic data from the OPAB data set. Note that the peak frequency of the seismic data changes at about $42.5 \mathrm{~km}$ along the profile

were carefully reviewed and quality controlled. As part of this process it became apparent that, for wells which reached the basement, there was a correlation between the gross Cambrian thickness and the thickness of the Faludden sandstone member for many wells (Fig. 5). On inspection of the map, it is clear that wells which do not fit this trend are located in a small area close to a body of water (Fårösund) between mainland Gotland and the northern island (Fårö). This correlation is also somewhat apparent in the cross section shown in Fig. 4, where the pinch out of the Faludden sandstone can be seen to coincide with a gradual decrease in the overall thickness of the Cambrian sequence. The geological implications of this trend are that the present-day extent and thickness of the Faludden reservoir beneath much of (from about $60 \mathrm{~Hz}$ in the south to about $120 \mathrm{~Hz}$ in the north) due to the use of different seismic sources. The frequency content of the synthetic seismograms was chosen to match the surrounding seismic. b Interpretation of the stratigraphy between the wells using the seismic data. Although no stratigraphy has formally been defined for the Silurian section, the seismic has been used to correlate some markers in the geophysical well logs, shown here as dashed lines. Note the decrease in the thickness of the Faludden sandstone reservoir from south to north

Gotland is controlled by erosion which occurred between the deposition of the Faludden sandstone and the Alum shale. The reason this trend is not present in the Fårösund area is because there are indications from the seismic and well data that significant tectonic activity occurred during the Cambrian, resulting in the gross thickness of the Cambrian being anomalously thin in this area. If the reservoir pinch out is controlled by erosion, it would imply that the reservoir quality will remain high up to the pinch out location. This would not be the case if the reservoir pinch out was due to a stratigraphic transition, where a gradual transition from sand to shale might be expected.

Before generating the final thickness map, the location of the reservoir pinch out was interpreted by hand based 
Fig. 5 Map of the thickness of the Faludden reservoir beneath Gotland. The inset graph in the top left-hand corner shows a cross plot of the Faludden reservoir thickness and the total Cambrian thickness, for wells which reach the basement. Wells which fit the linear trend line are shown as white dots, while wells which do not fit the trend line are shown as grey dots. The same colour scheme is used on the largescale map, where it is clear that the wells which do not fit the trend are located close to the strait between Gotland and the northern island (Fårö). Note that some offshore wells from the OPAB database used in the interpolation process lie outside of the area shown in the map (for example, the offshore wells shown in Sopher et al. 2014). The projection used for the map is RT90 $2.5 \mathrm{GONV}$

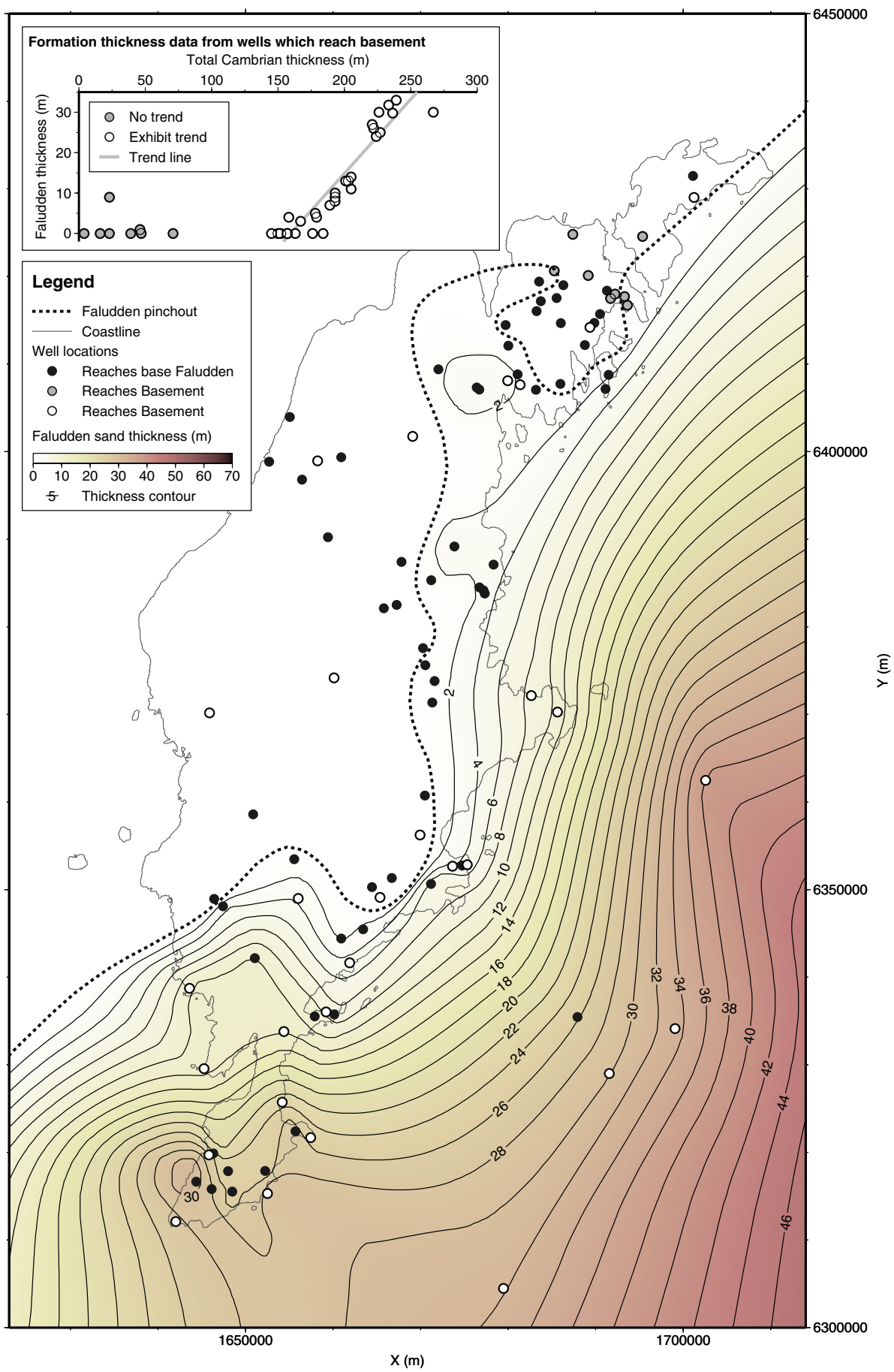

on the thickness data in the wells (Fig. 5). To constrain the interpretation of the pinch out location, the trend between the total Cambrian thickness and the Faludden thickness was utilized. Here, contours from a Cambrian thickness map generated from well data were used to guide the interpretation of the pinch out location. The well data were then interpolated to generate a map describing the thickness beneath Gotland. The performance of a range of different interpolation and filter combinations was tested using single well cross-validation analysis in Matlab (Geisser and Eddy 1979). Based on this testing, a natural neighbour interpolation was utilized, followed by a $2 \mathrm{D}$ median filter using a rectangular operator $(2.5 \mathrm{~km}$ and $5 \mathrm{~km}$ in the east-west and north-south directions, respectively). Using this scheme, the median average absolute error from the cross-validation analysis for the 130 wells used in the interpolation was $1.5 \mathrm{~m}$. Figure 5 shows the final Faludden reservoir thickness map beneath Gotland. It is 
clear from this map that, in terms of reservoir thickness alone, the most attractive area of Gotland for CAES is the southern part of the island where the Faludden reaches thicknesses in excess of $30 \mathrm{~m}$. The Faludden reservoir is present beneath the eastern edge of the island as far north as Fårö; however, it is relatively thin (0-14 m) compared to the southern part of Gotland. For the entire north western part of Gotland, CAES would not be viable within the Faludden, due to the absence of the reservoir.

\section{Faludden structure}

To date, no detailed structural maps of the Faludden reservoir beneath Gotland have been published. Therefore, an important part of this assessment was to generate a top structure map for the Faludden reservoir. This was accomplished using about 500 seismic lines for interpretation alongside well data. A small map detailing the locations of the 2D seismic profiles is shown in Fig. 6. A series of zero
Fig. 6 Map of the depth to the top of the Middle Cambrian. In areas where the Faludden sandstone is present, this is equivalent to the top of the reservoir. For each structural closure, a cross section through the closure is shown, which passes approximately through the highest point and spill point of each closure. The vertical exaggeration and horizontal scale is the same for all cross sections. Green areas on the cross sections indicate the parts of the Faludden reservoir within the closure, while yellow areas indicate parts of the reservoir outside the closure. The dark grey lines on the small inset map of Gotland at the bottom of the image show the location of the seismic profiles used to generate the main map. The projection used for the map is RT90 2.5 GONV

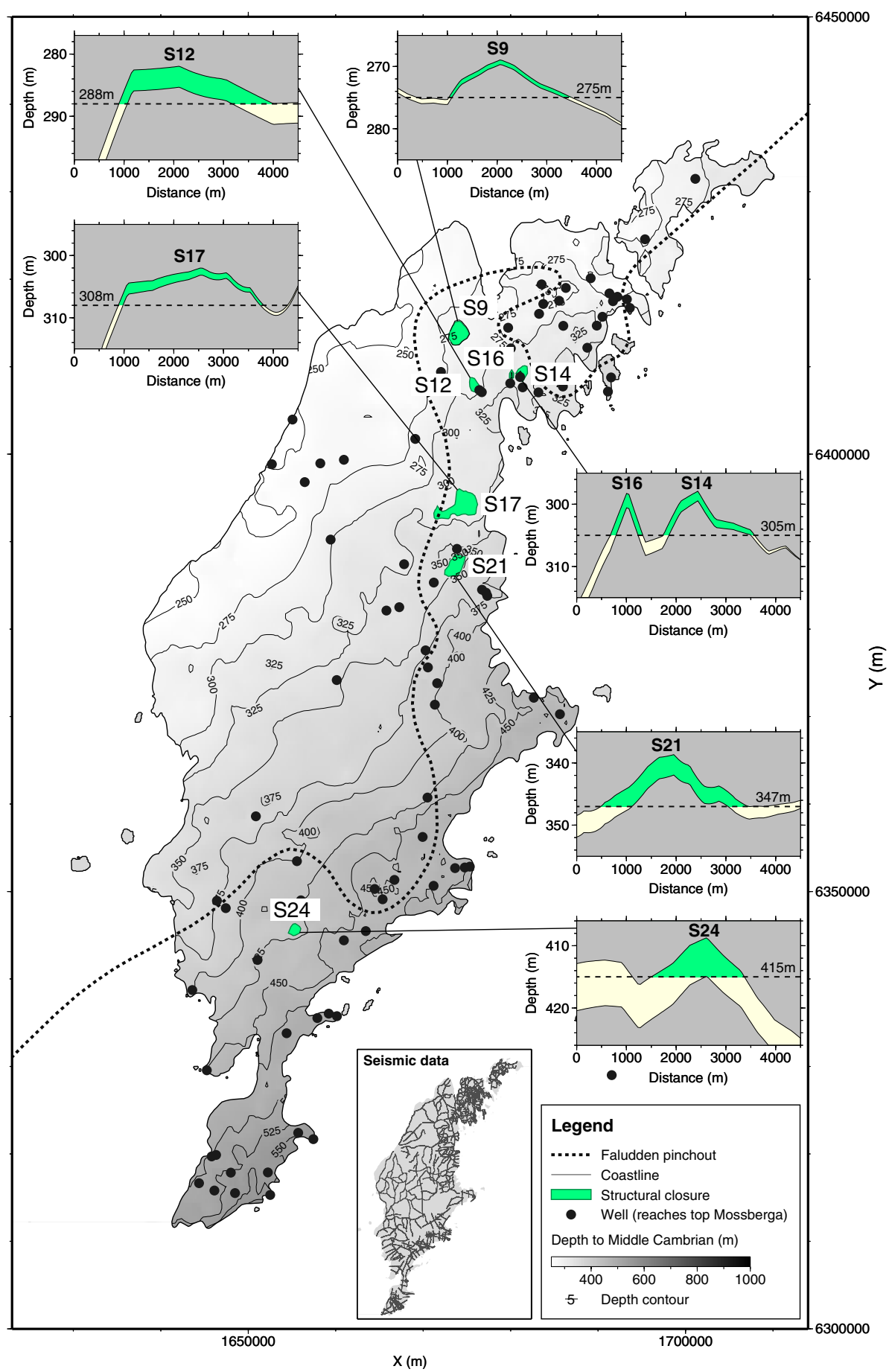


offset synthetic seismograms (Fig. 4) provide insight into the relationship between the seismic reflection data and the geological sequence. On inspection of the synthetic seismograms, the strongest seismic reflections are anticipated from the top and base of the Ordovician limestone succession. Utilizing well ties from 38 wells, the top and base Ordovician reflections were interpreted on all of the seismic lines. To generate the final top structure map, an isochore map for the interval between the top Ordovician and top Middle Cambrian was calculated and combined with the Top Ordovician map from Levendal et al. (2018). Interval velocities for the isochore map were derived at the well locations using the well data and seismic interpretation. These were then interpolated using Kriging in Matlab and then smoothed using a 2D rectangular median filter (10 km and $20 \mathrm{~km}$ in the east-west and north-south directions, respectively). Using this scheme, the median average absolute depth error in the top structure map from crossvalidation analysis for the 130 wells used in the interpolation was $5.7 \mathrm{~m}$. The final top structure map (Fig. 6) describes the depth to the top of the Middle Cambrian across Gotland. In parts of the island where the Faludden is present, this is equivalent to the top of the reservoir. The structure map shows a gentle dip to the south-east which is consistent with the regional trend (Sopher et al. 2016). Structural closures in areas where the Faludden reservoir is present have been highlighted as green areas. Note that only structural closures with a height of $5 \mathrm{~m}$ or more are shown. On inspection of the map in Fig. 6, it is clear that there are a few suitable structural closures in areas where the Faludden reservoir has a significant thickness. A number of structural closures exist below the north-eastern part of the island. However, in this area, the reservoir is only up to $4 \mathrm{~m}$ thick due to the proximity to the pinch out location. It is important to note that, in these areas, if the uncertainty in the thickness map is considered, that there is a risk that the reservoir is absent in some of these closures. In addition, it is often the case that the structural closures which appear on the top structure map (Fig. 6) are only defined by one or two seismic lines, and therefore, there is some uncertainty that a closure exists at these locations. Bearing this uncertainty in mind, the closures shown in Fig. 6 will be considered as potential CAES storage locations in the following sections. If the closure rating (Succar and Williams 2008) is calculated for the highest point on each of the structural closures, a value of 1 is obtained for all of the structures (Fig. 6). It should be noted that stratigraphic traps were also considered in the assessment (i.e. a structural trap bound on one side by the stratigraphic pinch out of the Faludden reservoir). However, no such traps were found when considering both the Faludden thickness and top structure maps together.

\section{Faludden reservoir and cap rock properties}

Despite the numerous wells drilled on Gotland, relatively few measurements of porosity and permeability are available within the OPAB database. A range of measurements were compiled from the OPAB database and combined with some additional measurements performed by the Geological Survey of Sweden (Table 2) (SwedSTORECO2 2013; Sopher et al. 2014). Based on these limited data, it is not possible to define a spatially varying estimate of porosity and permeability; instead, the mean average porosity and permeability are calculated. The mean average porosity and associated standard deviation for the Faludden on Gotland are 14.9\% and $4.1 \%$, respectively. While the mean average permeability and associated standard deviation for the Faludden on Gotland are $559 \mathrm{mD}$ and $544 \mathrm{mD}$, respectively. In terms of the type of reservoir, the Faludden sandstone is a relatively homogeneous, shallow marine sandstone deposit (Sopher et al. 2014). This is reflected in the relatively high net-togross value for the Faludden reservoir, where a mean average value of 0.9 was obtained from the analysis of wire-line $\operatorname{logs}$ from ten wells. Although no producible hydrocarbon accumulations were ever found within the Faludden sandstone reservoir beneath Gotland, the residual hydrocarbon saturation in the reservoir is quite high, at about 16\% (SwedSTORECO2 2013). On inspection of the available pressure data from the Faludden reservoir, it appears that the pressure is slightly above hydrostatic pressure (Fig. 7). In this study, a linear pressure depth relationship is assumed which provides the best fit with the available pressure data. Using this trend,

Table 2 Porosity and permeability measurements made from core data extracted from wells on Gotland for the Faludden reservoir

\begin{tabular}{llll}
\hline Well & Porosity $(\mathrm{pu})$ & $\begin{array}{l}\text { Vertical perme- } \\
\text { ability }(\mathrm{mD})\end{array}$ & $\begin{array}{l}\text { Horizontal } \\
\text { permeability } \\
(\mathrm{mD})\end{array}$ \\
\hline Källstäde-1 & 12.7 & 57 & \\
Furilden-1 & 11.7 & 39 & \\
Audungs-1 & 19.8 & 1750 & \\
Audungs-1 & 18.5 & 205 & \\
File Haidar & 10.2 & & \\
File Haidar & 10.2 & & \\
Faludden-2 & 18.7 & 1380 & \\
Faludden-2 & 19 & 1130 & \\
Hemse-1 & 8.2 & 0.15 & 752 \\
Hemse-1 & 10.5 & 1.18 & \\
Skåls-1 & 18.7 & & \\
Skåls-1 & & 373 & \\
Skåls-1 & 17.9 & 611 & \\
Skåls-1 & & 335 & \\
Hangre-1 & 16.1 & 703 & \\
Hangre-1 & 17 & &
\end{tabular}




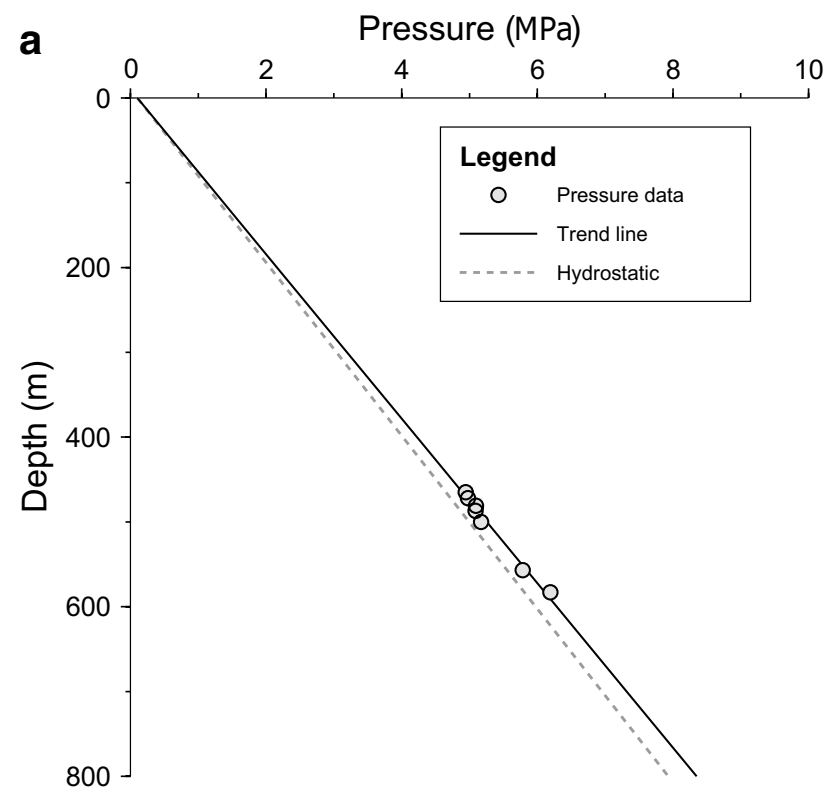

b

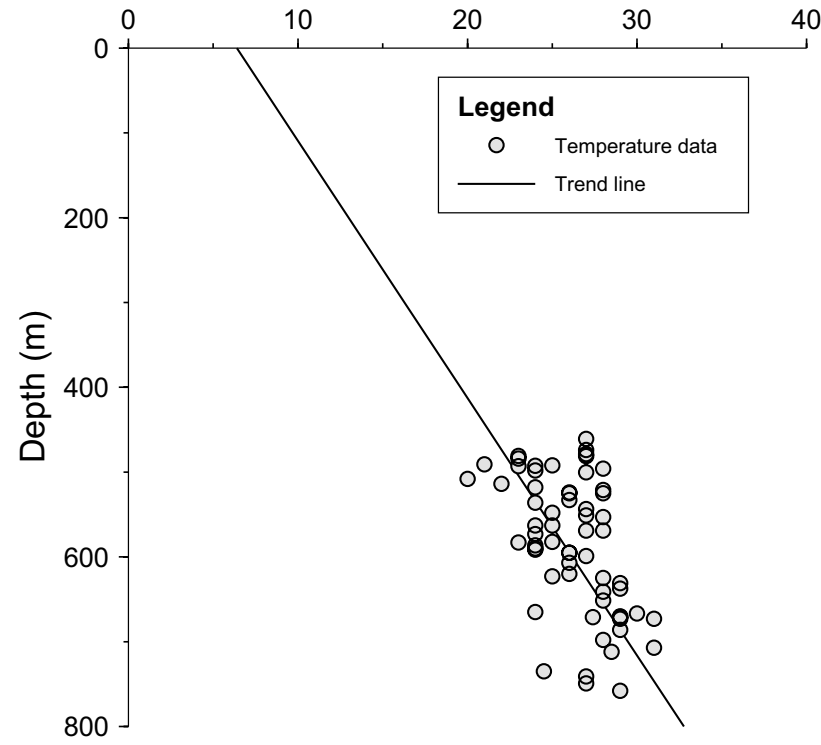

Fig. 7 a Faludden reservoir pressure measurements plotted against measurement depth. All measurements from the OPAB database, recorded beneath Gotland. b Bottom hole temperature measurements from wells on Gotland (OPAB database) plotted against measurement depth. Trend line calculated assuming an average surface temperature of $6.1^{\circ} \mathrm{C}$

reservoir pressures of between 2.87 and $4.31 \mathrm{MPa}$ are calculated for the different closures identified on the structure map (Fig. 6). Bottom hole temperature measurements from over 60 wells were collated from the OPAB database and a linear trend calculated, assuming an average surface temperature of $6.1^{\circ} \mathrm{C}$ (Fig. 7). Based on these data, it appears that a relatively high geothermal gradient of approximately $33^{\circ} \mathrm{C} /$ $\mathrm{km}$ is present on Gotland. Based on this trend, reservoir temperatures of between 15.3 and $19.8{ }^{\circ} \mathrm{C}$ are estimated for the different closures.

The properties of the Ordovician Bentonitic limestone unit, which is proposed as a cap rock above the Faludden reservoir, are also very important for assessing CAES feasibility (Giramonti et al. 1978). Permeability measurements taken for the Bentonitic limestone unit indicate values of less than $1 \mathrm{mD}$, and the thickness of the unit is between 45 and $60 \mathrm{~m}$ (SwedSTORECO2 2013; Sopher et al. 2014). Unfortunately, no measurements are available for the threshold pressure of the formation or data from pumping tests to check for cap rock leakage.

\section{Feasibility of CAES on Gotland}

If the criteria outlined in Table 1 are considered, then the majority of the reservoir properties appear favorable for the application of CAES on Gotland. The average porosity, average permeability, total closure rating, depth to top of reservoir, reservoir pressure, type of reservoir and cap rock thickness would all be considered good-to-excellent across the seven structural closures identified in the Faludden top structure map (Fig. 6). Unfortunately, it was not possible to assess some of the key parameters listed in Table 1 (e.g. cap rock threshold pressure and cap rock leakage) due to the absence of the necessary data in the OPAB database. Although the values for cap rock permeability are low $(<1$ $\mathrm{mD}$ ), it could not be confirmed that the permeability is lower than $10^{-5} \mathrm{mD}$, and hence, this is highlighted as a point of concern for potential CAES within the Faludden reservoir on Gotland. Furthermore, an additional point of concern is the relatively high residual hydrocarbon value of $16 \%$ within the reservoir. Such high residual concentrations may complicate a CAES operation in the Faludden reservoir. However, it is possible that risks associated with residual hydrocarbons could be mitigated (EPRI 1990). For example, injection of nitrogen or $\mathrm{CO}_{2}$ gas when forming the bubble can help to move residual hydrocarbons away from the wellbore before beginning the CAES operations (Succar and Williams 2008). Furthermore, in some projects, depleted hydrocarbon fields have been considered as targets for CAES pilot projects (EPRI 2012). Table 3 shows the numerical scores for each of the structural closures, using the ranking system proposed in Table 1 (Succar and Williams 2008). Based on these numerical values, it appears that all of the closures can be considered equally suitable for CAES applications, with the exception of closure S24, which is awarded a slightly higher score due to a more suitable reservoir pressure.

Utilizing the methodology outlined in "Subsurface CAES background", approximate energy storage capacities and flow rates were calculated for the structural closures in the 
Table 3 key properties of the structural closures within the Faludden reservoir on Gotland

\begin{tabular}{|c|c|c|c|c|c|c|c|}
\hline Closure & S9 & $\mathrm{S} 12$ & S14 & S16 & $\mathrm{S} 17$ & $\mathrm{~S} 21$ & $\mathrm{~S} 24$ \\
\hline Area of closure $\left(\mathrm{m}^{2}\right)$ & $4,125,000$ & $1,750,000$ & $1,750,000$ & 375,000 & $9,000,000$ & $3,875,000$ & $1,500,000$ \\
\hline Gross rock volume $\left(\mathrm{m}^{3}\right)$ & $2,728,387$ & $3,840,512$ & $1,976,797$ & 623,884 & $9,420,415$ & $9,757,416$ & $3,792,853$ \\
\hline Pore volume $\left(\mathrm{m}^{3}\right)$ & 365,877 & 515,013 & 265,089 & 83,663 & $1,263,278$ & $1,308,469$ & 508,622 \\
\hline Min closure depth (mBSL) & -269 & -282 & -295 & -297 & -301 & -339 & -408 \\
\hline Closure spill point (mBSL) & -275 & -288 & -305 & -305 & -308 & -347 & -415 \\
\hline Reservoir thickness in centre of closure (m) & 0.84 & 3.38 & 1.76 & 2.36 & 1.23 & 3.44 & 6.31 \\
\hline Confidence in structure & Medium & Medium & Medium & Medium & Medium & Medium & Low \\
\hline Reservoir temperature $\left({ }^{\circ} \mathrm{C}\right)$ & 15.3 & 15.7 & 16.1 & 16.2 & 16.3 & 17.6 & 19.8 \\
\hline Reservoir pressure $(\mathrm{MPa})$ & 2.87 & 3.01 & 3.14 & 3.16 & 3.20 & 3.60 & 4.31 \\
\hline $\begin{array}{l}\text { CAES score using ranking table from Succar } \\
\text { and Williams (2008) }\end{array}$ & 38 & 38 & 38 & 38 & 38 & 38 & 39 \\
\hline Energy storage capacity low estimate (MWh) & 37 & 52 & 27 & 8 & 126 & 131 & 51 \\
\hline Energy storage capacity high estimate (MWh) & 366 & 515 & 265 & 84 & 1263 & 1308 & 509 \\
\hline Flow rate $(\mathrm{Kg} / \mathrm{s})$ & 34.6 & 124.1 & 68.6 & 102.1 & 65.6 & 192.5 & 262.4 \\
\hline
\end{tabular}

The confidence in the structure is assessed based on the appearance of the closure in the seismic reflection data. The numerical ranking from the assessment using Table 1 outlined by Succar and Williams (2008) is also shown for each closure. Estimated energy storage capacities and flow rates for the closures are also shown

Faludden reservoir (Table 3). To calculate the total pore space of the closures, constant porosity and net-to-gross values of $14.9 \%$ and 0.9 were assumed, respectively. Based on these results, closures S17 and S21 have the highest estimated energy storage capacity of between 126 and 1308 MWh. In the high case, these storage capacities are large enough to be relevant for industrial-scale energy storage, being comparable to the Huntorf CAES plant. However, it is clear that storage within structural closures within the Faludden reservoir would not be sufficient to meet the maximum potential energy storage requirement on Gotland, estimated in "Energy production and storage requirement on Gotland" $(26 \mathrm{GWh})$. Where the sum of the high case storage capacities for all seven structures amounts to about $4.31 \mathrm{GWh}$. To calculate the flow rates shown in Table 3, a constant difference of 1.8 MPa was assumed between the high and low pressures in the CAES cycle, which is similar to the Huntorf CAES plant. It was also assumed that the wellbore radius was $125 \mathrm{~mm}$ (about 5 inches) and that the drainage area for the well is $1 \mathrm{~km}$. A constant permeability of $559 \mathrm{mD}$ (the mean average value for the core data) was assumed for all of the closures. Furthermore, in an attempt to account for the 1D nature of Eq. 2, it was assumed that the thickness of the reservoir was the average height of the reservoir above the closure (i.e. the total volume of the closure, divided by the area). To convert the estimated flow rates from volume to mass, air density values were chosen based on the reservoir conditions. Based on these calculations, flow rates of between 35 and $262 \mathrm{Kg} / \mathrm{s}$ were estimated from the closures on Gotland, where the highest flow rates are anticipated for the S21 and S24 closures. Although these flow rates are very approximate, they are of the right order of magnitude for
CAES to be feasible. For example, the Huntorf CAES plant requires a flow of $417 \mathrm{Kg} / \mathrm{s}$ to produce $321 \mathrm{MW}$ of power per hour (Kushnir et al. 2012).

Cost is an important factor which is not addressed in detail in this assessment. However, it is possible to perform a simple cost estimate based on the high case storage capacity estimate for the $\mathrm{S} 21$ closure in this study supported by values from Luo et al. (2015). Here, a plant with a total storage capacity of $1300 \mathrm{MWh}$, power output of $70 \mathrm{MW}$ for $18.5 \mathrm{~h}$, and operating time of 10 years is assumed. Estimated costs for such a plant are between 46 and $226 \mathrm{M} \$$. If cost calculations for the same plant are made for a range of different battery storage technologies (Lead-acid, Sodiumsulfur, Nickel-cadmium, and Vanadium reflux flow batteries), then estimated costs for these solutions are two-to-ten times those of the CAES plant (Luo et al. 2015). If costs for hydrogen fuel cells are calculated based on the values in Luo et al. (2015), then costs for CAES appear to be comparable, albeit slightly lower. Therefore, based on these simple calculations, CAES would appear to be competitive economically with other energy storage techniques which could be implemented on Gotland.

\section{Discussion}

The results from this preliminary study indicate that the Faludden reservoir appears to be favorable for the application of CAES in many respects. Although it is unlikely that CAES within the seven closures (Fig. 6) will be able to meet the total estimated energy storage demand on Gotland in the future, early indications of the flow rate and energy storage 
capacity appear to be high enough for industrial scale CAES to be feasible. Hence, it appears that CAES could provide a valuable component in an energy storage solution on Gotland. However, it is clear that more extensive and detailed characterization work is required to further assess its potential. Firstly, reservoir simulation work is required to gain insight into the dynamic behaviour of compressed air within the structural closures and to perform more accurate estimates of potential storage capacity and reservoir flow rate. Presently, there is a lack of information about some key reservoir and cap rock properties. This could be addressed by drilling a well to collect core and also perform dynamic testing within the reservoir (e.g. testing reservoir flow rates/ pump tests). There is also significant uncertainty in the structure of the closures identified in the Faludden reservoir, which could be reduced through the acquisition of a dense grid of seismic reflection data over the closures. To further assess the feasibility of CAES on Gotland, it would also be important to perform an accurate assessment of the engineering and economic requirements of a surface CAES facility. In this study, the geochemical or microbiological aspects of a CAES operation within the Faludden reservoir are not considered. For example, injection of air could lead to chemical reactions or microbial activity within the reservoir that could result in dissolution or clogging. Therefore, to gain a better understanding of the feasibility of the Faludden reservoir for CAES it would be important to investigate how the presence of air could affect the reservoir quality over the lifetime of a CAES operation (e.g., over periods of 10-50 years). Finally, it would be important to contact and meet with representatives from other parts of society (e.g. the community on Gotland, industry and governmental organizations) to educate and get feedback on potential CAES related ideas on Gotland.

In this assessment, the focus has been on storage within closures. Some studies have investigated the potential to apply porous reservoir CAES within a flat or gently dipping reservoir where no structural closure exists (Fig. 8). Typically, these studies have shown that, depending on the timescale of storage, there is good potential to store energy in such a scenario (Jarvis 2015). In this assessment, it is clear that the Faludden reservoir is relatively flat and does not have an abundance of large structural closures, which is a limitation on the storage capacity. However, if storage in a flat or gently dipping reservoir is feasible on Gotland, then it would greatly increase the potential energy storage capacity (perhaps by a factor of 10-100) and increase the locations where CAES facilities could be constructed. Due to the dynamic nature of the scenario, it is most meaningful to investigate this further using reservoir simulation.

\section{Conclusion}

In this study, an assessment of the characteristics and geometry of the Faludden reservoir beneath Gotland was conducted, where, for the first time, a detailed thickness map and top structure map for the Faludden reservoir are presented. Key reservoir properties such as temperature, pressure, porosity and permeability are also characterised for the Faludden reservoir. Formation thickness data are used to infer that the present-day extent and thickness of the reservoir is controlled by Middle Cambrian and Late Cambrian erosion. This reservoir information is then used to perform a preliminary assessment of the CAES storage potential on Gotland. Results from this assessment show that the majority of the properties of the Middle Cambrian Faludden reservoir and Ordovician Bentonitic Limestone cap rock are apparently suitable for CAES. Based on the top Faludden reservoir structure map, seven structural closures were identified, predominantly on the eastern side of the island, which could be utilized for CAES. Key concerns for the suitability of CAES in the Faludden reservoir are the presence of residual hydrocarbons and uncertainty in the structure and reservoir properties within these closures. Scoping calculations show that the energy storage capacity within one of the more promising structures identified in the Faludden reservoir is between 130 and $1300 \mathrm{MWh}$. Estimates also show a

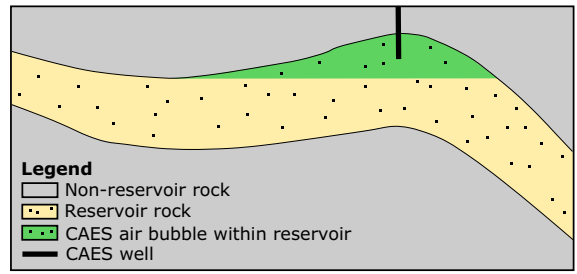

Fig. 8 Different scenarios for storage of air within a subsurface porous reservoir in CAES. a CAES scenario considered in this study, storage of an air bubble within a structural closure. b Potential CAES scenario which could be investigated using reservoir modeling, where the air bubble would not be trapped within a structural closure. Such b

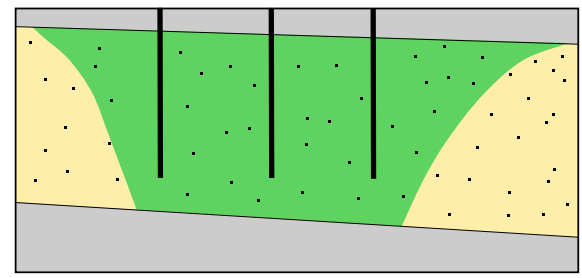

a scenario would only be viable if the movement of the air bubble does not occur at a rate which significantly affects the efficiency of the storage operation, over timescales important for storage on Gotland 
that the flow rate from the reservoir within some of these closures is of the right order of magnitude for CAES to be applied. Therefore, based on this preliminary assessment, it appears that CAES within the Faludden reservoir could be a viable energy storage option on Gotland worthy of further investigation. It also highlights the potential of subsurface CAES to facilitate the development of additional renewable energy and to help work towards a $100 \%$ fossil-fuel free energy system on Gotland.

Acknowledgements The Swedish Research Council (VR) partly funded Daniel Sopher during this research (Project number 2010-3657) and is gratefully acknowledged. GLOBE ClaritasTM under license from the Institute of Geological and Nuclear Sciences Limited, Lower Hutt, New Zealand was used to process the seismic data after vectorization. Björn Bergman and Sverker Olsson at the Geological Survey of Sweden (SGU) are thanked for their input and for providing data. Two anonymous reviewers are thanked for their comments which were very helpful to improve the manuscript.

Open Access This article is distributed under the terms of the Creative Commons Attribution 4.0 International License (http://creativeco mmons.org/licenses/by/4.0/), which permits unrestricted use, distribution, and reproduction in any medium, provided you give appropriate credit to the original author(s) and the source, provide a link to the Creative Commons license, and indicate if changes were made.

\section{References}

Aghahosseini A, Breyer C (2018) Assessment of geological resource potential for compressed air energy storage in global electricity supply. Energy Convers Manag 169:161-173

Allen RD, Doherty TJ (1984) Outcome of compressed air energy storage at Pittsfield, Illinois. United States. In: Intersociety energy conversion engineering conference, San Francisco, CA, USA

Allen RD, Doherty TJ, Erikson RL, Wiles LE (1983) Factors affecting storage of compressed air in porous rock reservoirs. Pacific Northwest Laboratory, Battelle, p 157

Barton JP, Infield DG (2004) Energy storage and its use with intermittent renewable energy. IEEE Trans Energy Convers 19:441-448

Byman K (2015) Location study_power to gas. Energiforsk AB, Stockholm, p 69

Calner M, Jeppsson L, Munnecke A (2004) The Silurian of GotlandPart I: review of the stratigraphic framework, event stratigraphy, and stable carbon and oxygen isotope development. Erlanger geologische Abhandlungen-Sonderband 5. Field guide, pp 113-131

Chen H, Cong TN, Yang W, Tan C, Li Y, Ding Y (2009) Progress in electrical energy storage system: a critical review. Prog Nat Sci 19:291-312

Crotogino F, Mohmeyer KU, Scharf R (2001) Huntorf CAES: more than 20 years of successful operation. Solution Mining Research Institute Meeting Orlando, Florida

EPRI (1990) Compressed-air energy storage: Pittsfield aquifer field test. Test data: engineering analysis and evaluation. EPRI GS-6688, Palo Alto

EPRI (2012) Sacramento municipal utility district (SMUD) compressed air energy storage plant. EPRI, Palo Alto

Eriksson ME, Calner M (2005) The dynamic silurian earth: subcommision on silurian stratigraphhy field meeting 2005. Sver Geol Unders Rapp Meddeland 121:6-99
Erlström M, Fredriksson D, Juhojuntti N, Sivhed U, Wickström L (2011) Lagring av koldioxid i berggrunden - krav, förutsättningar och möjligheter. Sver Geol Unders Rapp Meddeland 131:7-94

Geisser S, Eddy WF (1979) A predictive approach to model selection. J Am Stat Assoc 74(365):153-160

Giramonti AJ, Lessard RD, Blecher WA, Smith EB (1978) Conceptual design of compressed air energy storage electric power systems. Appl Energy 4:231-249

Green A, Sorby A (2018) Energiläget 2017 - En avstämning av Gotlands klimat- och energimål. Länsstyrelsen i Gotlands län 2018:3

Hagenfeldt S (1994) The Cambrian File Haidar and Borgholm Formations in the central Baltic and south central Sweden. Stockholm Contrib Geol 43(2):69-110

Hagenfeldt S, Bjerkéus M (1991) Cambrian acritarch stratigraphy in the central Baltic Sea, Sweden. Geologiska Föreningen i Stockholm Förhandlingar 113(1):83-84. https://doi.org/10.1080/11035 899109453831

Heath JR, Bauer SJ, Broome ST, Dewers TA, Rodriguez MA (2013) Petrologic and petrophysical evaluation of the Dallas center structure, Iowa, for compressed air energy storage in the mount simon sandstone. In: Sandia National Laboratories. SAND2013-0027, p 89

Jankauskas T (1994) The Cambrian. In: Grigelis A, Kadknas V (eds) Geology of Lithuania. Publishing Geological Institute of Lithuania, Vilnius, pp 35-45 (in Lithuanian)

Jarvis AS (2015) Feasibility study of porous media compressed air energy storage in South Carolina, United States of America. Clemson University. All Theses. Paper 2256

Katz DL, Cornell D, Kobayashi R, Poettmann FH, Vary JA, Elenbaas JR, Weinaug CF (1959) Handbook of natural gas engineering. McGraw-Hill, New York

Kilda L, Friis H (2002) The key factors controlling reservoir quality of the Middle Cambrian Deimena Group sandstone in West Lithuania. Bull Geol Soc Den 49:25-39

Kushnir R, Dayan A, Ullmann A (2012) Temperature and pressure variations within compressed air energy storage caverns. Int $\mathbf{J}$ Heat Mass Transf 55:5616-5630

Levendal TC, Sopher D, Lehnert O, Erlström M, Juhlin C (2018) Ordovician mounds of the western Baltoscandian Basin in time and space - a geophysical approach. Palaeogeogr Palaeoclimatol Palaeoecol (under review)

Lothe A, Emmel B, Bergmo P, Mortensen GM, Frykman P (2015) Updated estimate of storage capacity and evaluation of Seal for selected Aquifers (D26). NORDICCS Technical Report D 6.3.1401 (D26), p 80

Luo X, Wang J, Dooner M, Clarke J, Krupke C (2014) Overview of current development in compressed air energy storage technology. Energy Procedia 62:603-611

Luo X, Wang J, Dooner M, Clarke J (2015) Overview of current development in electrical energy storage technologies and the application potential in power system operations. Appl Energy 137:511-536

Molenaar N, Cyziene J, Sliaupa S (2007) Quartz cementation mechanisms and porosity variation in Baltic Cambrian sandstones. Sed Geol 195:135-159. https://doi.org/10.1016/j.sedgeo.2006.07.009

Nielsen A, Schovsbo N (2011) The Lower Cambrian of Scandinavia: depositional environment, sequence stratigraphy and palaeogeography. Earth Sci Rev 107:207-310

Nilsson K, Soares J, Ivanell S (2017) Energy transition Gotland: Renewable resources and system effects. Internal report. Uppsala Universitet, Gotland

Nironen M (1997) The Svecofennian Orogen: a tectonic model. Precambr Res 86:21-44

OECD/IEA, Nordic Energy Research, Technical University of Denmark, Ea Energianalyse A/S, VTT Technical Research Centre of 
Finland, University of Iceland, Institute For Energy Technology, Profu $\mathrm{Ab}$ and IVL Swedish Environmental Research Institute (2016) Nordic energy technology perspectives. IEA, Paris

Oldenburg CM, Pan L (2013) Porous media compressed-air energy storage (PM-CAES): theory and simulation of the coupled wellbore-reservoir system. Transp Porous Media 97:201-221

Poprawa P, Sliaupa S, Stephenson R, Lazauskiene J (1999) Late Vendian-Early Palaeozoic tectonic evolution of the Baltic Basin: regional tectonic implications from subsidence analysis. Tectonophysics 314:219-239

Power RWE (2010) ADELE-Adiabatic compressed-air energy storage (CAES) for electricity supply. RWE Power. http://www.rwe. $\mathrm{com} / \mathrm{web} / \mathrm{cms} / \mathrm{mediablob} / \mathrm{en} / 391748 /$ data/235554/1/rwe-power -ag/press/company/Brochure-ADELE.pdf. Accessed 13 June 2018

Raju M, Khaitan KS (2012) Modeling and simulation of compressed air storage in caverns: a case study of the Huntorf plant. Appl Energy 89:474-481

Region G (2014) Energi 2020: energiplan för Region Gotland. Region Gotland. http://www.gotland.se/37457. Accessed 20 Aug 2018

SCB (2018) Statistiska centralbyrån, Sverige. http://www.statistikd atabasen.scb.se/goto/sv/ssd/ProdbrEl Accessed 20 Aug 2018

Schaber C, Mazza P, Hammerschlag R (2004) Utility-scale storage of renewable energy. Electr J 17:21-29

SLR and Uppsala University (2014) Final report on prospective sites for the geological storage of $\mathrm{CO}_{2}$ in the southern Baltic Sea. Elforsk Rep 14:53

Sopher D (2017) Converting scanned images of seismic reflection data into SEG-Y format. Earth Sci Inf 11:241-255

Sopher D, Juhlin C (2013) Processing and interpretation of vintage 2D marine seismic data from the outer Hanö Bay Area, Baltic Sea. J Appl Geophys 95:1-15

Sopher D, Juhlin C, Erlström M (2014) A probabilistic assessment of the effective $\mathrm{CO} 2$ storage capacity within the Swedish sector of the Baltic Basin. Int J Greenh Gas Control 20:148-170
Sopher D, Erlström M, Bell N, Juhlin C (2016) The structure and stratigraphy of the sedimentary succession in the Swedish sector of the Baltic Basin: new insights from vintage $2 \mathrm{D}$ marine seismic data. Tectonophysics 676:90-111

Succar S, Williams RH (2008) Compressed air energy storage: theory, resources, and applications for wind power. Princeton Environmental Institute, Princeton, p 81

SwedSTORECO2 (2013) Potential for $\mathrm{CO}_{2}$ storage in Swedish bedrock: SwedSTORECO2-Phase 1. Final report, p 125

Ūsaityte D (2000) The geology of the southeastern Baltic Sea: a review. Earth Sci Rev 50:137-225

Van der Linden S (2006) Bulk energy storage potential in the USA, current developments and future prospects. Energy 31:3446-3457

Vernon R, O'Neil N, Pasquali R, Nieminen M (2013) Screening of prospective sites for geological storage of $\mathrm{CO}_{2}$ in the Southern Baltic Sea. Espoo 2013. VTT Technol 101:58 pp

Wang B, Bauer S (2017) Compressed air energy storage in porous formations: a feasibility and deliverability study. Petrol Geosci 23:306-314

Yang Z, Tian L, Jung B, Joodaki S, Fagerlund F, Pasquali R (2015) Assessing $\mathrm{CO}_{2}$ storage capacity in the Dalders Monocline of the Baltic Sea Basin using dynamic models of varying complexity. Int J Greenh Gas Control 43:149-160

Zhang G, Li B, Zheng D, Ding G, Wei H, Qian P, Li C (2017) Challenges to and proposals for underground gas storage (UGS) business in China. Nat Gas Ind B 4(3):231-237

Publisher's Note Springer Nature remains neutral with regard to jurisdictional claims in published maps and institutional affiliations. 